\section{Effect of lubricants on apically extruded debris and dentinal crack formation using ProTaper Next and Reciproc systems}

Lubrikantların apikalden taşan debris miktarı ve dentin çatlağı üzerine etkisinin ProTaper Next ve Reciproc sistemleri kullanılarak değerlendirilmesi

\section{Assist. Prof. Burhan Can Çanakçi}

Trakya University, Faculty of Dentistry, Department of Endodontics, Edirne

\section{Prof. Özgür Er}

Trakya University, Faculty of Dentistry, Department of Endodontics, Edirne

Received: 29 May 2017

Accepted: 12 October 2017

doi: 10.5505/yeditepe.2018.36035

\section{Corresponding author:}

Assist. Prof. Burhan Can Çanakçi

Trakya Üniversitesi, Balkan Yerleşkesi, Endodonti A.D. Edirne

Phone: 05058829070

E-mail: burhancanakci@trakya.edu.tr

\section{SUMMARY}

Aim: We evaluated the effects of $5 \% \mathrm{NaOCl}$ solution, $17 \%$ EDTA solution, and RC-Prep on the amount of apically extruded debris and the incidence of dentinal cracks during canal preparation using the ProTaper Next and Reciproc systems.

Materials and Methods: In total, 255 human mandibular incisors were divided into eight groups ( $\mathrm{n}=30$ each) and a control group $(n=15)$. Teeth in groups $1(\mathrm{NaOCl}), 2$ (EDTA), 3 (RC-Prep), and 4 (EDTA+RC-Prep) were prepared using the ProTaper Next system, and those in groups 5 ( $\mathrm{NaOCl}), 6$ (EDTA), 7 (RC-Prep), and 8 (EDTA+RC-Prep) were prepared using the Reciproc system. Apical extrusion and crack formation were each examined in 15 teeth from each group. Extruded debris was collected in pre-weighed Eppendorf tubes. In the crack detection study, teeth were sectioned horizontally at 3,6, and $9 \mathrm{~mm}$ from the apex. The slices were then viewed through a stereomicroscope at $\times 25$ magnification.

Results: Among ProTaper Next groups, the amount of debris extruded was significantly greater in group $1(\mathrm{NaOCl})$ than in groups 2 (EDTA), 3 (RC-Prep), and 4 (EDTA+RC-Prep; $\mathrm{p}<$ 0.001 ). No significant difference was detected among groups 2,3 , and 4. Among Reciproc groups, the amount of debris extruded was significantly greater in group $5(\mathrm{NaOCl})$ than in groups 6 (EDTA), 7 (RC-Prep), and 8 (EDTA+RC-Prep; $p<$ 0.001). No significant difference was observed among groups 6,7 , and 8 . The total numbers of cracks were significantly larger in groups 1 (ProTaper - NaOCl), 3 (ProTaper - RC-Prep), 5 (Reciproc - $\mathrm{NaOCl}$ ), and 7 (Reciproc - RC-Prep) than in groups 2 (ProTaper - EDTA), 4 (ProTaper - EDTA+RC-Prep), 6 (Reciproc - EDTA), and 8 (Reciproc - EDTA+RC-Prep).

Conclusions: Within the limitations of this study, EDTA solution or RC-Prep causes less apical extrusion. The use of EDTA solution produced fewer dentinal cracks, and the use of RCPrep alone did not affect.

Keywords: Apical extrusion, dentinal crack, EDTA, lubricant

\section{ÖZET}

Amaç: Kök kanallarının ProTaper Next (Dentsply Maillefer, Ballaigues, İsviçre) ve Reciproc (VDW, Münih, Almanya) sistemleri ile şekillendirilmesi sırasında \%5'lik NaOCl çözeltisi, \%17'lik EDTA çözeltisi ve RC-Prep (Premier Dental, Philadelphia, PA, USA) kullanımının apikalden taşan debris miktarı ve dentin çatlağı oluşumu üzerindeki etkisi değerlendirilmiştir.

Gereç ve Yöntem: 255 insan mandibular keser diş sekiz grup $(n=30)$ ve kontrol grubu $(n=15)$ olarak ayrılmıştı. Grup 1 (NaOCl), 2 (EDTA), 3 (RC-Prep) ve 4 (EDTA+RC-Prep) ProTaper Next sistemi ile, grup 5 (NaOCl), 6 (EDTA), 7 (RC-Prep) ve 8 (EDTA+RC-Prep) Reciproc sistemi ile şekillendirilmiștir. Apikal taşma ve çatlak oluşumu değerlendirmeleri için her gruptan 15 örnek kullanılmıştır. Taşan debris, daha önceden ağırığı tespit edilmiş olan Eppendorf tüplerine biriktirilmiştir. İşlem süreleri kaydedilmiştir. Çatlak tespiti için dişler apeksten 3, 6 
ve 9 mm uzaklıklardan düşük hız ve su soğutması altında yatay olarak kesilmiştir. Kesitler $\times 25$ büyütme altında steryomikroskop ile incelenemiştir.

Bulgular: Apikalden taşan debris değerlendirildiğinde, ProTaper Next grupları arasında grup 1'de ( $\mathrm{NaOCl})$; grup 2 (EDTA), 3 (RC-Prep) ve 4 (EDTA+RC-Prep; $p<0.001$ )'den daha fazla debris taşmıştır. Grup 2, 3 ve 4 arasında ise fark tespit edilmemiştir. Reciproc gruplarından grup 5 'de ( $\mathrm{NaOCl}$ ); grup 6 (EDTA), 7 (RC-Prep) ve 8 (EDTA+RC-Prep; $p<0.001$ )'den daha fazla debris taşmıştır. Grup 6, 7 ve 8 arasında ise fark tespit edilmemiştir. Çatlak tespit deneyinin sonuçlarına göre deney grupları ve kontrol grubu arasında istatistiksel olarak belirgin fark görülmüştür. Toplam çatlak sayıları değerlendirildiğinde grup 1 (ProTaper - NaOCl), 3 (ProTaper - RC-Prep), 5 (Reciproc - NaOCl) ve 7 (Reciproc - RC-Prep)'de grup 2 (ProTaper - EDTA), 4 (ProTaper - EDTA+RC-Prep), 6 (Reciproc - EDTA) ve 8 (Reciproc - EDTA+RC-Prep)'den daha fazla çatlak ortaya çıkmıştır.

Sonuçlar: Bu çalışmanın sınırları dahilinde, EDTA çözeltisi yada RC-Prep kullanımı apikalden taşan debris miktarını azaltmıştır. EDTA çözeltisi çatlak oluşumunu azaltırken, sadece RC-Prep kullanımının etkisi olmamıştır.

Anahtar kelimeler: Apikalden taşma, dentin çatlağı, EDTA, lubricant

\section{INTRODUCTION}

During chemo-mechanical preparation, many factors, such as the extrusion of debris containing dentine chips, remnants of pulpal tissue, irrigating solution, microorganisms and by-products, may lead to postoperative inflammation, flare ups, and short- and long-term failure. ' In addition, preparation procedures can damage the root dentine, resulting in dentinal cracks $^{2,3}$ that have the potential to develop into vertical root fractures ${ }^{4}$ and lead to the extraction of the tooth. ${ }^{5}$

Several studies have demonstrated that all preparation techniques and instruments cause the extrusion of some debris. ${ }^{6-8}$ The effects of the design (size and type) and kinematics of endodontic instruments and of preparation techniques on the amount of apical debris extruded have been investigated widely. ${ }^{9-11}$ In addition, several studies have investigated the effects of different irrigation systems and techniques on apically extruded debris and irrigants. $^{12-14}$

Despite several advantages, instrumentation with $\mathrm{NiTi}$ files can induce microcrack formation at different levels of the root canal walls. ${ }^{15,16}$ Several rotating and reciprocating NiTi systems have been designed to enable easier, faster, safer, and better root canal shaping. ProTaper Next (Dentsply Maillefer, Ballaigues, Switzerland) instruments have off-centre rectangular designs and progressive- and regressive-percentage tapers on single files, which are made using M-Wire technology. The off-centre rectangular design minimises contact between the file and the dentine and decreases the screw effect, potentially dangerous taper lock, and torque on any given file. ${ }^{17}$ The Reciproc (VDW, Munich, Germany) single-file NiTi system was also produced using M-Wire technology to increase the flexibility of the instrument. ${ }^{18}$ Reciproc files are used with a reciprocating motion to reduce stress on the instrument and to minimise the occurrence of fractures due to cyclic fatigue. ${ }^{19}$

Ethylenediamine tetraacetic acid (EDTA) is a calcium-chelating agent that can act as a lubricant during root canal preparation, ${ }^{20}$ increase antibacterial activity, ${ }^{21}$ and remove the smear layer. ${ }^{22}$ Although irrigants such as sodium hypochlorite $(\mathrm{NaOCl})$ may serve as lubricants like EDTA, paste-type substances containing EDTA are marketed especially for this purpose. Manufacturers of rotary systems routinely recommend the use of these paste-type preparations to reduce stress on instruments and/or to improve hard-tissue debridement. ${ }^{23}$

To our knowledge, no reported study has compared the effects of $17 \%$ EDTA, $5 \% \mathrm{NaOCl}$ solutions and paste-type lubricant on the amount of apically extruded debris and the incidence of root canal cracks during root canal preparation procedures. The aim of this study was to evaluate the effects of $5 \% \mathrm{NaOCl}$ solution, $17 \%$ EDTA solution, and RC-Prep (Premier Dental, Philadelphia, PA, USA) on the amount of apically extruded debris and the incidence of dentinal cracks during canal preparation using two different NiTi systems.

\section{MATERIALS AND METHODS}

In total, 255 freshly extracted human mandibular incisors with mature apices and straight root canals were selected $^{24}$ and kept in purified filtered water. All teeth were analysed using digital radiography in the buccal and proximal directions to confirm that they had single canals and apical foramina, and uncomplicated root canal anatomy. The soft-tissue remnants and calculus on the external root surfaces were removed by hand devices. To standardize specimen lengths, all teeth were shortened to $16 \mathrm{~mm}$ by flattening of the incisal edge with a low-speed saw (Isomet; Buehler Ltd., Lake Bluff, IL, USA) under water cooling. The root surfaces were examined under an operating microscope (OPMI Pico; Carl Zeiss, Oberkochen, Germany) to enable the exclusion of specimens with external defects or cracks. Under the operating microscope, the working length (WL) was determined as $1 \mathrm{~mm}$ short of the length of a size $15 \mathrm{~K}$-file that was visible at the major apical foramen.

The samples were divided randomly into eight experimental groups ( $n=30$ each) and a control group $(n=15)$. 
Group 1 (G1: ProTaper - NaOCl). ProTaper Next instruments (\#17 .04, \#25 .06) were used to the WL with gentle in-and-out brushing motion, according to the manufacturer's instructions. For each specimen, a total of $15 \mathrm{~mL} 5 \%$ $\mathrm{NaOCl}$ was used for irrigation between files and pecking sequences.

Group 2 (G2: ProTaper - EDTA). The same procedure was used as in G1, except that a total of $10 \mathrm{~mL} \mathrm{NaOCl}$ and $5 \mathrm{~mL}$ 17\% EDTA were used.

Group 3 (G3: ProTaper - RC-Prep). The same procedure was used as in G1, except that RC-Prep was applied to the cutting edges of files before insertion.

Group 4 (G4: ProTaper - EDTA+RC-Prep). The same procedure was used as in G1, except that a total of $10 \mathrm{~mL}$ $\mathrm{NaOCl}$ and $5 \mathrm{~mL}$ EDTA were used and RC-Prep was applied to the cutting edges of the files before insertion.

Group 5 (G5: Reciproc - NaOCl). A Reciproc instrument (\#25 .08) was used to the $\mathrm{WL}$, with a reciprocating slow in-and-out pecking motion according to the manufacturer's recommendation. For each specimen, a total of 15 $\mathrm{mL} \mathrm{NaOCl}$ was used for irrigation between files and pecking sequences.

Group 6 (G6: Reciproc - EDTA). The same procedure was used as in G5, except that a total of $10 \mathrm{~mL} \mathrm{NaOCl}$ and $5 \mathrm{~mL}$ EDTA were used.

Group 7 (G7: Reciproc - RC-Prep). The same procedure was used as in G5, except that RC-Prep was applied to the cutting edges of files before insertion.

Group 8 (G8: Reciproc - EDTA+RC-Prep). The same procedure was used as in G5, except that a total of $10 \mathrm{~mL}$ $\mathrm{NaOCl}$ and $5 \mathrm{~mL}$ EDTA were used and RC-Prep was applied to the cutting edges of the files before insertion.

Group 9 (G9). G9 ( $n=15)$ served as a control group for the crack detection study; no preparation was done.

For all samples, $5 \mathrm{~mL}$ distilled water was used for the final irrigation. Apical canal patency was controlled with a size $15 \mathrm{~K}$-file. Instruments were used to prepare a single canal per specimen. All root canal preparations were completed by a single operator.

\section{Apical extrusion study}

In total, 120 teeth ( $n=15 /$ group) were used for the apical extrusion study. Teeth were placed in the vial system, which had been pre-weighed three times using an analytical balance (AUW-220D; Shimadzu, Tokyo, Japan) with an accuracy of $10^{-5} \mathrm{~g}$. Holes were created in the rubber stoppers of vials with a hot instrument. Each tooth was inserted under pressure through the rubber stopper, which was fixed to the cemento-enamel junction using cyanoacrylate (Quickstar; Furkan Inc., Istanbul, Turkey). The rubber stopper with the tooth was then fitted into the mouth of the vial. The apical part of the root was suspended within the vial, which acted as a collecting container for the apical material extruded through the foramen of the root.
A 25-G needle was placed through the rubber stopper to equalise the air pressure inside and outside the vial. After the instrumentation was complete, the stopper, needle, and tooth were separated from the Eppendorf tube, and the debris that adhered to the root surface was collected by washing the root with $1 \mathrm{~mL}$ distilled water while in the tube. The vials were stored in an incubator at $68^{\circ} \mathrm{C}$ for 5 days to evaporate the moisture before weighing the dry debris. Glass vials that included dry extruded debris were weighed in the same manner as during the initial measurement. The weight of the extruded debris was determined by subtracting the weight of the pre-weighed empty glass vials from the weight of the tubes containing dried debris. The durations of preparation periods were also recorded.

\section{Crack detection study}

In total, 135 teeth ( $n=15$ /group) were used for the crack detection study. The surfaces of the experimental roots were coated with a silicone impression material to simulate the periodontal ligament space. All roots were then embedded in acrylic blocks.

After root canal preparation was performed as described above, all experimental and control (no preparation) samples were sectioned perpendicular to the long axis at 3,6 , and $9 \mathrm{~mm}$ from the apex with a low-speed saw under water cooling. Then, the slices were viewed through a stereomicroscope (DM750; Leica, Wetzlar, Germany) and pictures were taken with a digital camera (D-Lu×3, Leica, Germany) attached to the stereomicroscope at a magnification of $\times 25$. Crack formation was classified using the categories 'no crack' and 'crack'. 'No crack' was defined as the absence of cracks and craze lines in root dentine on the internal (canal) or external (root) surface. 'Crack' was defined as any line observed on the slice that extended from the root canal lumen to the dentine or from the outer root surface into the dentine. ${ }^{25}$

\section{Statistical analysis}

Data on the amount of apically extruded debris and time required for preparation were subjected to one-way analysis of variance and Tukey's tests. Data for the crack detection study were subjected to $x 2$ tests. The SPSS software (ver. 22.0; SPSS, Chicago, IL, USA) was used. The statistical significance level was set at $p<0.05$.

\section{RESULTS}

\section{Apical extrusion}

The median weights of the extruded debris are presented in Table 1. Significant differences in the amount of extruded debris among groups are presented in Table 2. The median preparation durations are shown in Table 3.

Among ProTaper Next groups, the amount of debris extruded was significantly greater in $\mathrm{G} 1(\mathrm{NaOCl})$ than in $\mathrm{G} 2$ (EDTA), G3 (RC-Prep), and G4 (EDTA+RC-Prep). No signifi- 
cant difference was detected among G2, G3, and G4.

Table 1. Median weight of apically extruded debris (10-5 g)

\begin{tabular}{|l|l|l|}
\hline Group 1 & ProTaper - NaOCl & Median (25\%-75\%) \\
\hline Group 2 & ProTaper - EDTA & $129(107-143,5)$ \\
\hline Group 3 & ProTaper - RC-Prep & $67(58,5-77,5)$ \\
\hline Group 4 & ProTaper - EDTA+RC-Prep & $52(58,5-101)$ \\
\hline Group 5 & Reciproc - NaOCl & $88(83-113,5)$ \\
\hline Group 6 & Reciproc - EDTA & $69(58-83)$ \\
\hline Group 7 & Reciproc - RC-Prep & $69(49-82,5)$ \\
\hline Group 8 & Reciproc - EDTA+RC-Prep & $48(42-56,5)$ \\
\hline
\end{tabular}

Table 2. Significant differences of the amount of extruded debris between experimental groups.

\begin{tabular}{|l|c|c|c|c|c|c|c|c|}
\hline & $\begin{array}{c}\text { PT } \\
\text { NaOCl }\end{array}$ & $\begin{array}{c}\text { PT } \\
\text { EDTA }\end{array}$ & $\begin{array}{c}\text { PT } \\
\text { RcPrep }\end{array}$ & $\begin{array}{c}\text { PT } \\
\text { EDTA+RC }\end{array}$ & $\begin{array}{c}\text { Rec } \\
\text { NaOCl }\end{array}$ & $\begin{array}{c}\text { Rec } \\
\text { EDTA }\end{array}$ & $\begin{array}{c}\text { Rec } \\
\text { RcPrep }\end{array}$ & $\begin{array}{c}\text { Rec } \\
\text { EDTA+RC }\end{array}$ \\
\hline PT- NaOCl & & $*$ & $*$ & $*$ & $*$ & $*$ & $*$ & $*$ \\
\hline PT-EDTA & $*$ & & & & $*$ & & & \\
\hline PT-Rc-Prep & $*$ & & & & & & & $*$ \\
\hline PT- EDTA+Rc & $*$ & & & & $*$ & & & \\
\hline Rec-NaOCl & $*$ & $*$ & & $*$ & & $*$ & $*$ & $*$ \\
\hline Rec-EDTA & $*$ & & & & $*$ & & & \\
\hline Rec-Rc-Prep & $*$ & & & & $*$ & & & \\
\hline Rec-EDTA+Rc & $*$ & & $*$ & & $*$ & & & \\
\hline
\end{tabular}

* indicated statistically difference. $(p<.001)$

Table 3. Median time values.

\begin{tabular}{|l|l|l|}
\hline Group 1 & ProTaper - NaOCl & Median (25\%-75\%) \\
\hline Group 2 & ProTaper - EDTA & $81(67-103)^{\mathrm{a}}$ \\
\hline Group 3 & ProTaper - RcPrep & $76(74-81)^{\mathrm{a}}$ \\
\hline Group 4 & ProTaper - EDTA+RC-Prep & $65(41-68)^{\mathrm{b}}$ \\
\hline Group 5 & Reciproc - NaOCl $(49-86)^{\mathrm{b}}$ \\
\hline Group 6 & Reciproc - EDTA & $51(42-73)^{\mathrm{c}}$ \\
\hline Group 7 & Reciproc - RC-Prep & $43(38-51)^{\mathrm{d}}$ \\
\hline Group 8 & Reciproc - EDTA+RC-Prep & $37(32-46)^{\mathrm{d}}$ \\
\hline Different letters indicated statistically difference. $(p<.001)($ seconds).
\end{tabular}

Among Reciproc groups, the amount of debris extruded was significantly greater in $\mathrm{G} 5$ ( $\mathrm{NaOCl}$ ) than in G6 (EDTA), G7 (RC-Prep), and G8 (EDTA+RC-Prep). No significant difference was observed among G6, G7, and G8.

Among all groups, the amount of debris extruded was significantly greater in $\mathrm{G} 1$ (ProTaper - NaOCl) than in G5 (Reciproc - NaOCl), G6 (Reciproc - EDTA), G7 (Reciproc - RCPrep), and G8 (Reciproc - EDTA+RC-Prep). This amount was significantly greater in $\mathrm{G} 5$ (Reciproc - $\mathrm{NaOCl}$ ) than in G2 (ProTaper - EDTA) and G4 (ProTaper EDTA+RC-Prep), and in G3 (ProTaper - RC-Prep) than in G8 (Reciproc - EDTA+RC-Prep).

Among ProTaper Next groups, preparation time was sig- nificantly shorter in G3 (RC Prep) and G4 (EDTA+RC-Prep) than in $\mathrm{G} 1$ ( $\mathrm{NaOCl}$ ) and G2 (EDTA). The preparation time was significantly longer in $\mathrm{G} 5$ (Reciproc - $\mathrm{NaOCl}$ ) than in the other Reciproc groups, but shorter in G5 than in all ProTaper Next groups.

\section{Crack formation}

The percentage and number of cracks are presented in Table 4. The control group had no crack. Significant differences were observed between the control and experimental groups. The experimental groups showed no significant difference among sections $(3,6$, and $9 \mathrm{~mm})$.

The total numbers of cracks were significantly larger in G1 (ProTaper - NaOCl), G3 (ProTaper - RC-Prep), G5 (Reciproc - NaOCl), and G7 (Reciproc - RC-Prep) than in G2 (ProTaper - EDTA), G4 (ProTaper - EDTA+RC-Prep), G6 (Reciproc - EDTA), and G8 (Reciproc - EDTA+RC-Prep).

Table 4. Number and percentage of cracks in the different cross-section slices.

\begin{tabular}{|l|l|l|l|l|}
\hline & $3 \mathrm{~mm}$ & $6 \mathrm{~mm}$ & $9 \mathrm{~mm}$ & Total Cracks \\
\hline ProTaper - NaOCl & $4(26.6 \%)$ & $3(20 \%)$ & $3(20 \%)$ & $10(22.2 \%)^{\mathrm{a}}$ \\
\hline ProTaper - EDTA & $2(13.3 \%)$ & $1(6.6 \%)$ & $1(6.6 \%)$ & $4(8.8 \%)^{\mathrm{b}}$ \\
\hline ProTaper - RC-Prep & $4(26.6 \%)$ & $3(20 \%)$ & $1(6.6 \%)$ & $8(17.7 \%)^{\mathrm{a}}$ \\
\hline ProTaper - EDTA+RcPrep & $1(6.6 \%)$ & $2(13.3 \%)$ & $1(6.6 \%)$ & $4(8.8 \%)^{\mathrm{b}}$ \\
\hline Reciproc - NaOCl & $4(26.6 \%)$ & $3(20 \%)$ & $2(13.3 \%)$ & $9(20 \%)^{\mathrm{a}}$ \\
\hline Reciproc- EDTA & $2(13.3 \%)$ & $1(6.6 \%)$ & $1(6.6 \%)$ & $4(8.8 \%)^{\mathrm{b}}$ \\
\hline Reciproc - RC-Prep & $3(20 \%)$ & $3(20 \%)$ & $2(13.3 \%)$ & $8(17.7 \%)^{\mathrm{a}}$ \\
\hline Reciproc - EDTA+RcPrep & $1(6.6 \%)$ & $1(6.6 \%)$ & $1(6.6 \%)$ & $3(6.6 \%)^{\mathrm{b}}$ \\
\hline Control & 0 & 0 & 0 & $0^{\mathrm{c}}$ \\
\hline
\end{tabular}

Different letters indicated statistically difference. $(p<.05)$

\section{DISCUSSION}

Chemo-mechanical preparation may cause apical extrusion of debris ${ }^{26}$ and dentinal cracks, ${ }^{2}$ leading to the failure of root canal treatments. ${ }^{5,27}$ The effects of different NiTi systems ${ }^{10,11}$ and irrigation methods/systems ${ }^{12,13}$ on apical extrusion have been investigated. In addition, the effects of different NiTi systems on the incidence of dentinal cracks has been investigated widely. ${ }^{15,16}$ However, no reported study has investigated the effects of EDTA and lubricants on the amount of apically extruded debris and incidence of dentinal cracks. Thus, in this study, we aimed to compare the amount of apically extruded debris and incidence of dentinal cracks resulting from the use of $5 \% \mathrm{NaOCl}, 17 \%$ EDTA, and RC-Prep with two different NiTi systems (ProTaper Next, Reciproc).

\section{Apical extrusion}

The results of this study showed that the use of EDTA and/or RC-Prep caused significantly less apical extrusion of debris than did the use of $\mathrm{NaOCl}$ alone in the ProTaper Next and Reciproc groups. In addition, the use of EDTA+RC-Prep caused less debris extrusion than did the use of EDTA or RC-Prep alone, but these differences were not significant. To our knowledge, no reported study has 
investigated the effects of EDTA solution or RC-Prep on the amount of apically extruded debris. Thus, no previous data are available for comparison with our findings.

EDTA solution can decrease the microhardness of dentine. ${ }^{28-30}$ The softening of dentine caused by chelating solutions may facilitate the cutting and removal of dentine during instrumentation, resulting in less debris extrusion. A scanning electron microscopic analysis of root canal walls ${ }^{28}$ revealed the presence of a wax-like smear layer, attributed to the polyethylene glycol base of an EDTAurea peroxide-polyethylene glycol compound, after preparation. Another study showed that neither irrigation nor further preparation was able to remove radioactive glycerol completely after the use of $2.5 \% \mathrm{NaOCl}$ with an EDTAurea peroxide-14 C-labeled glycerol paste. ${ }^{31}$ During preparation with RC-Prep, dentinal debris may penetrate into this non-removable layer, reducing the amount of apically extruded debris. In addition, the peroxides in RC-Prep can decrease the microhardness of dentine, ${ }^{32}$ which may increase the effectiveness of instrumentation and decrease the amount of apically extruded debris.

The combined use of EDTA solution and RC-Prep caused significantly less debris extrusion than observed for other treatments in this study. The combined effects of lubrication and smear removal by EDTA solution and EDTA gel may help to push the dentinal debris in the coronal direction.

The comparison of NiTi systems employed with the same irrigation protocols (G1 vs. G5, G2 vs. G6, G3 vs. G7, G4 vs. G8) showed that use of the Reciproc system caused significantly less apical extrusion than did the use of the ProTaper Next system. This finding may be explained by the reciprocating action, which is a type of mechanised, balanced, forced, pressure-less technique, of the Reciproc system. ${ }^{33}$ In addition, differences in file design may have affected the amount of apically extruded debris. ${ }^{34}$ The Reciproc system has an S-shaped cross section, sharp cutting edges, and no radial land, ${ }^{35}$ whereas ProTaper Next files have an off-centre rectangular design.

Borges.${ }^{11}$ and Silva ${ }^{36}$ reported no significant difference in the outcomes of use of the ProTaper Next and Reciproc systems. However, in both studies, files with different apical sizes and tapers (Reciproc R40 and ProTaper Next $\mathrm{X} 4$ ) were used, with distilled water serving as the irrigation solution. Topçuoğlu ${ }^{37}$ also used the Reciproc R40, ProTaper Next X4, and distilled water, and reported that the Reciproc caused more debris extrusion than did the ProTaper Next. These differences may be attributed to differences in apical size and taper of NiTi systems, as well as the irrigation solution used.

\section{Crack formation}

The results of this study showed that the incidence of dentinal cracks was similar in the RC-Prep and $\mathrm{NaOCl}$ groups instrumented with the ProTaper Next and Reciproc systems. Alireza ${ }^{38}$ and Aydin ${ }^{39}$ reported similar results. Although RC-Prep acts as a lubricant during canal preparation, the wax-like smear layer caused by RC-Prep ${ }^{28}$ may be thick and contain dentinal debris, and thus may increase the incidence of dentinal cracks.

No significant difference between the EDTA and EDTA+RC-Prep groups was observed in specimens instrumented with the ProTaper Next or Reciproc system; however, both of these groups showed significantly fewer dentinal cracks then did the $\mathrm{NaOCl}$ and RC-Prep groups. Compared with $\mathrm{NaOCl}$, EDTA has a better chelating effect and can cause a greater decrease in the microhardness of root canal dentine..$^{40}$ The more effective lubrication of EDTA may increase the effectiveness of instrumentation and reduce the incidence of dentinal cracks.

In this study, the incidence of dentinal cracks did not differ between groups instrumented with the ProTaper Next and Reciproc systems. Priya ${ }^{41}$ found no difference between groups instrumented with the two NiTi systems, with $\mathrm{NaOCl}$ alone used for irrigation.

Regardless of the irrigation protocol, significantly less time was required for preparation in the Reciproc groups. Among ProTaper Next groups, preparation was significantly faster in the RC-Prep and EDTA+RC-Prep groups than in the $\mathrm{NaOCl}$ and EDTA groups. Preparation was slower in the Reciproc $\mathrm{NaOCl}$ group than in the other $\mathrm{Re}$ ciproc groups, but it was faster in this group than in all ProTaper Next groups.

\section{CONCLUSIONS}

In the instrumentation of root canals with the ProTaper Next and Reciproc systems, the use of 17\% EDTA solution or RC-Prep causes less apical extrusion than does the use of $5 \% \mathrm{NaOCl}$ solution. The use of EDTA solution or EDTA+RC-Prep produced fewer dentinal cracks, and the use of RC-Prep alone did not affect the incidence of dentinal cracks.

\section{ACKNOWLEDGMENTS}

The authors deny any conflicts of interest related to this study.

\section{REFERENCES}

1. Seltzer S, Naidorf IJ. Flare-ups in endodontics: I. Etiological factors. J Endod 1985; 11: 472-478.

2. Liu R, Hou BX, Wesselink PR, Wu M-K, Shemesh $\mathrm{H}$. The incidence of root microcracks caused by 3 different single-file systems versus the ProTaper system. J Endod 2013; 39: 1054-1056. 
3. Hin ES, Wu M-K, Wesselink PR, Shemesh $\mathrm{H}$. Effects of self-adjusting file, Mtwo, and ProTaper on the root canal wall. J Endod 2013; 39: 262-264.

4. Wilcox LR, Roskelley C, Sutton T. The relationship of root canal enlargement to finger-spreader induced vertical root fracture. J Endod 1997; 23: 533-534.

5. Tamse A, Fuss Z, Lustig J, Kaplavi J. An evaluation of endodontically treated vertically fractured teeth. J Endod 1999; 25: 506-508.

6. Al-Omari M, Dummer P. Canal blockage and debris extrusion with eight preparation techniques. J Endod 1995; 21: 154-158.

7. Reddy SA, Hicks ML. Apical extrusion of debris using two hand and two rotary instrumentation techniques. J Endod 1998; 24: 180-183.

8. Azar NG, Ebrahimi G. Apically-extruded debris using the protaper system. Aust Endod J 2005; 31: 21-23.

9. Üstün $Y$, Çanakçi $B$, Dinçer $A$, Er O, Düzgün $S$. Evaluation of apically extruded debris associated with several $\mathrm{Ni}$-Ti systems. Int Endod J 2015; 48: 701-704.

10.Ferraz C, Gomes N, Gomes B, Zaia A, Teixeira F, SouzaFilho $\mathrm{F}$. Apical extrusion of debris and irrigants using two hand and three enginedriven instrumentation techniques. Int Endod J 2001; 34: 354-358.

11. Borges $A \dot{H}$. The influence of cervical preflaring on the amount of apically extruded debris after root canal preparation using different instrumentation systems. J Endod 2016; 42: 465-469

12. Yost RA. Evaluation of 4 different irrigating systems for apical extrusion of sodium hypochlorite. J Endod 2015; 41: 1530-1534.s

13. İriboz E, Bayraktar K, Türkaydın D, Tarçın B. Comparison of apical extrusion of sodium hypochlorite using 4 different root canal irrigation techniques. J Endod 2015; 41: 380-384.

14. Yeter K, Evcil M, Ayranci L, Ersoy I. Weight of apically extruded debris following use of two canal instrumentation techniques and two designs of irrigation needles. J Endod 2013; 46: 795-799.

15. Bier CAS, Shemesh $H$, Tanomaru-Filho $M$, Wesselink $\mathrm{PR}, \mathrm{Wu} \mathrm{M}-\mathrm{K}$. The ability of different nickel-titanium rotary instruments to induce dentinal damage during canal preparation. J Endod 2009; 35: 236-238.

16. Ashwinkumar V, Krithikadatta J, Surendran S, Velmurugan $\mathrm{N}$. Effect of reciprocating file motion on microcrack formation in root canals: an SEM study. Int Endod J 2014; 47: 622-627.

17. Ruddle CJ. The ProTaper endodontic system: geometries, features, and guidelines for use. Dent Today. 2001; 20: 60-67.

18. Berutti E . Canal shaping with WaveOne Primary reciprocating files and ProTaper system: a comparative study. J Endod 2012; 38: 505-509.
19. De-Deus G, Vieira VTL, da Silva EJN, Lopes $H$, Elias $\mathrm{CN}$, Moreira EJ. Bending resistance and dynamic and static cyclic fatigue life of Reciproc and WaveOne large instruments. J Endod 2014; 40: 575-579.

20. Hülsmann $M$, Heckendorff $M$, Lennon $A$. Chelating agents in root canal treatment: mode of action and indications for their use. Int Endod J 2003; 36: 810-830.

21. Byström A, Sunvqvist G. The antibacterial action of sodium hypochlorite and EDTA in 60 cases of endodontic therapy. Int Endod J 1985; 18: 35-40.

22.Çalt S, Serper A. Time-dependent effects of EDTA on dentin structures. J Endod 2002; 28: 17-19.

23. Peters $\mathrm{O}$, Boessler $\mathrm{C}$, Zehnder $\mathrm{M}$. Effect of liquid and pastetype lubricants on torque values during simulated rotary root canal instrumentation. Int Endod J 2005; 38: 223-229.

24. Schneider SW. A comparison of canal preparations in straight and curved root canals. Oral Surg Oral Med Oral Pathol 1971; 32: 271-275.

25. Shemesh $\mathrm{H}$, Bier $\mathrm{C}$, Wu MK, Tanomaru Filho M, Wesselink P. The effects of canal preparation and filling on the incidence of dentinal defects. Int Endod J 2009; 42: 208213.

26. Ruiz-Hubard EE, Gutmann JL, Wagner MJ. A quantitative assessment of canal debris forced periapically during root canal instrumentation using two different techniques. J Endod 1987; 13: 554-558.

27. Huang $X$, Ling J, Wei X, Gu L. Quantitative evaluation of debris extruded apically by using ProTaper Universal Tulsa rotary system in endodontic retreatment. J Endod 2007; 33: 1102-1105.

28. Verdelis K, Ellades G, Ovllr T, Margelos J. Effect of chelating agents on the molecular composition and extent of decalcification at cervical, middle and apical root dentin locations. Dent Traumatol 1999; 15: 164-170.

29. Cruz-Filho AM, Sousa-Neto MD, Saquy PC, Pecora JD. Evaluation of the effect of EDTAC, CDTA, and EGTA on radicular dentin microhardness. J Endod 2001; 27: 183-184. 30. Ari $\mathrm{H}$, Erdemir A, Belli S. Evaluation of the effect of endodontic irrigation solutions on the microhardness and the roughness of root canal dentin. J Endod 2004; 30: 792-795.

31. Zurbriggen T, Del Rio C, Brady J. Postdebridement retention of endodontic reagents: a quantitative measurement with radioactive isotope. J Endod 1975; 1: 298-299.

32. Lewinstein I, Hirschfeld Z, Stabholz A, Rotstein I. Effect of hydrogen peroxide and sodium perborate on the microhardness of human enamel and dentin. $J$ Endod 1994; 20: 61-63.

33. Yared G. Canal preparation using only one NiTi rotary instrument: preliminary observations. Int Endod J 2008; 41: 339-344.

34. Beeson T, Hartwell G, Thornton J, Gunsolley J. Com- 
parison of debris extruded apically in straight canals: conventional filing versus profile. 04 Taper series 29. J Endod 1998; 24:18-22.

35. Bürklein S, Schäfer E. Apically extruded debris with reciprocating single-file and full-sequence rotary instrumentation systems. J Endod 2012; 38: 850-852.

36. Silva E . Comparison of apically extruded debris after large apical preparations by fullsequence rotary and singlefile reciprocating systems. Int Endod J 2016; 49: 700705.

37. Topçuoğlu H . Apically extruded debris during root canal preparation using Vortex Blue, K3XF, ProTaper Next and Reciproc instruments. Int Endod J 2016; 49: 11831187.

38. Adl A, Sedigh-Shams M, Majd M. The effect of using $\mathrm{RC}$ prep during root canal preparation on the incidence of dentinal defects. J Endod 2015; 41: 376-379.

39. Aydin U, Aksoy F, Karataslioglu E, Yildirim C. Effect of ethylenediaminetetraacetic acid gel on the incidence of dentinal cracks caused by three novel nickel titanium systems. Aust Endod J 2015; 41: 104-110.

40. Saleh A, Ettman W. Effect of endodontic irrigation solutions on microhardness of root canal dentine. J Dent 1999; 27: 43-46.

41. Priya NT . "Dentinal microcracks after root canal preparation." A comparative evaluation with hand, rotary and reciprocating instrumentation. J Clin Diagn Res 2014; 8: 70-72. 
